уроці відповідно до теми.

Отже, розвиток творчих здібностей дитини на уроці музики залежить від ініціативи та майстерності вчителя в доборі музичного матеріалу до уроку та методів роботи 3 ним. Застосування прийомів імпровізації на уроках музики $є$ одним із ефективних засобів розвитку творчої активності школярів.

\title{
Література
}

1. Ветлугіна Н. О. Музичний розвиток дитини / Н. О. Ветлугіна. - Київ : Муз. Україна, 1978. - 256 с. 2. Ростовський О.Я. Педагогіка музичного сприймання / О. Я. Ростовський. - Київ : ІЗМН, 1997. - 248 с. З. Асафьев В. В. Избранные статьи о музыкальном просвещении и образовании. - [2-е изд.]. / В. В. Асафьев. - Ленинград : Музыка, 1973. - 144 с. 4. Выготский Л. С. Воображение и творчество в детском возрасте: Психологический почерк. - [3-е изд.]. / Л. С. Выготский. - Москва : Просвещение, 1991. $93 \mathrm{c}$.

Любов Шиачук

\section{ФОРМУВАННЯ ТВОРЧИХ ЗДІБНОСТЕЙ МОЛОДШИХ ШКОЛЯРІВ У НАВЧАЛЬНО-ВИХОВНОМУ ПРОЦЕСІ ПОЧАТКОВОЇ ШКОЛИ}

Шпачук Л. Р. Формування творчих здібностей молодших школярів у навчальновиховному процесі початкової школи.

У статті, спираючись на сучасні досягнення педагогічної науки та практики, визначаються найбільш дієві дидактичні умови як засіб формування творчих здібностей молодших школярів, що з успіхом можуть бути використані на уроках рідної мови у початковій школі.

Ключові слова: творчість, креативні освітні технології, інтеграція, інтерактивне й ігрове навчання.

Шпачук Л. Р. Формирование творческих способностей младших школьников в учебно-воспитательном процессе начальной школы.

В статье на основе анализа современных достижений педагогической науки и практики определяются наиболее действенные дидактические условия как средства формирования творческих способностей младших школьников, которые с успехом могут быть использованы на уроках родного языка в начальной школе.

Ключевые слова: творчество, креативные образовательные технологии, интеграция, интерактивное и игровое обучение.

Shpachuk L. R. Formation of creative abilities of junior pupils in the educational process at primary school.

In the article based on the analysis of current achievements of pedagogical science and practice the most effective didactic conditions as means of formation of creative abilities of junior pupils are determined. These conditions should be used at the native language lessons at a primary school. It also focuses the attention on the effective methods, ways and forms of teaching.

Key words: creativity, creative educational technology, integration, interactive and game training, basic research methods of education. 
Проблема формування творчих здібностей молодших школярів, зокрема на уроках рідної мови, вже протягом тривалого часу є предметом уваги представників різних галузей знань. Залишається вона на часі й на сучасну пору, про що свідчать численні розвідки у психолого-педагогічній і методичній науці (Л. Варзацька, М. Вашуленко, Л. Виготський, Г. Вусик, М. Девдера, С. Коновець, Г. Костюк, М. Коченгіна, І. Кравцова, О. Павлик, О. Полєвікова, Л. Порох, О. Савченко, А. Сологуб та ін.).

На їхнє переконання, у кожній дитині природою закладений певний творчий потенціал. А от виявити творчі здібності, розвинути їх якомога повніше - це завдання, яке стоїть перед кожним учителем початкової ланки освіти. Для цього він має навчити дитину не тільки творчо мислити, а й бачити прекрасне в навколишньому світі, тонко сприймати його; грамотно, образно і влучно висловлювати свої думки, вподобання, враження і міркування в усній чи писемній формі. Робота ця копітка, самовіддана, об'ємна, довготривала, то ж вимагає не тільки часу, а й системної організації.

Свого часу Л. Виготський слушно зазначав, що навчання створює зону найближчого розвитку, тобто породжує в дитини цілу низку внутрішніх процесів розвитку, які є для неї можливими тільки у сфері стосунків з людьми, але які, внутрішньо розвиваючись, стають внутрішнім надбанням дитини [1, с. 15].

Безперечно, навчання 3 цієї точки зору не є розвитком, але правильно організоване навчання дитини зумовлює іiі розумовий розвиток, який поза навчанням неможливий, бо навчання - це внутрішньо необхідний і загальний момент у процесі розвитку в дитини не природних, а історичних особливостей людини. Процеси розвитку не збігаються з процесами навчання; процеси розвитку йдуть за процесами навчання, що створюють зону найближчого розвитку [1, с. 15].

Педагог же передовсім спрямовує i коригує розумову i творчу діяльність своїх вихованців, послуговуючись продуманою, майстерною i динамічною методикою, розробленою з урахуванням вікових особливостей, нахилів учнів, їх творчих здібностей і можливостей.

Для цього в арсеналі сучасної педагогіки та лінгводидактики існує чимало технологій, які 3 огляду на їх креативну спрямованість, творчо активізувальні цілі й розвивальновиховний характер та безпосередній зв'язок з різними видами мистецтва розглядаються як креативні освітні технології. До них, згідно з позицією С. Коновець, відносять: особистісно зорієнтовану, Вальдорфську педагогіку, технологію саморозвитку, технологію розвивального навчання, технологію формування творчої особистості, технологію колективної творчої діяльності й виховання, технологію створення ситуації успіху та інтеграцію [4, с. 21].

Креативні освітні технології варто визнавати ефективним способом здійснення таких еволюційних процесів, як модернізація та вдосконалення вітчизняної системи освіти й виховання та цілеспрямований і послідовний творчий розвиток кожної дитини.

3-поміж креативних освітніх технологій вирізняється передусім антропософська педагогічна система - Вальдорфська педагогіка, яку виправдано вважають сучасною духовно-науковою екологією становлення особистості [4, с. 22; 14]. Вона розглядається як система самопізнання й саморозвитку кожної особистості засобами мистецтва в умовах свободи навчання, виховання й творчості, у двоєдності чуттєвого та надчуттєвого досвіду духу, душі й тіла.

Не менш результативною, на думку Л. Варзацької, М. Вашуленка, С. Коновець, I. Кравцової, О. Савченко та інших, освітньою технологією є інтеграція. Головна їі мета - 
допомогти дітям виробити цілісне бачення навколишнього світу та самих себе, зайняти певну життєву позицію щодо природи і суспільства [5, с. 9].

Важливим резервом у процесі творчого розвитку школярів у сучасній школі $є$ така креативна технологія, як колективна творча діяльність і виховання, що являє собою особистісно зорієнтовану систему формування пізнавально-світоглядної, почуттєвої та діяльнісно-творчої сфери особистості школяра.

На переконання С. Коновець, «колективні форми творчої діяльності можуть бути досить результативними не лише на урочних заняттях, а й у позакласній роботі, оскільки у процесі спільної взаємодії не тільки одного, а навіть кількох учнівських гуртків може здійснюватися справжня співтворчість, яка дарує радість та емоційно-естетичне задоволення як колективу загалом, так і його членам зокрема» [4, с. 25].

При цьому не залишаються поза увагою традиційні форми навчання, але вони модифікуються і вдосконалюються, поєднуючи раціональні та емоційні види діяльності, надаючи простір для ініціативи дітей.

Так, для розвитку творчих здібностей, інтелектуального потенціалу рекомендовано використовувати (враховуючи рівень підготовки учнів): проблемні, дослідницькі та пошукові методи навчання. Під керівництвом педагога учень включається в пошук істини i досягає іï розкриття власними зусиллями або простежує від думки вчителя. У такий спосіб молодший школяр отримує не готові знання, а здобуває їх самостійно, вчиться мислити. Це передовсім творчі завдання, які дають кожному учневі можливість саморозкритися.

За М. Наумчук і Л. Лушпинською, «творчі роботи - це сукупність таких видів вправ, під час виконання яких проявляється висока самостійність учнів; вправи, у яких учні створюють новий текст, складають усні і письмові оповідання, замальовки, гуморески, повідомлення про результати спостережень, досліджень. У творчих роботах розкриваються особистість школярів, їх почуття, погляди, життєва позиція» [8, с. 121].

М. Девдера, М. Коченгіна, Н. Максимова, О. Павлик, Л. Порох також уважають, що високі потенційні можливості для розвитку творчих здібностей молодших школярів криються в письмових роботах, оскільки «в різних типах і видах письмових робіт є більш чи менш виражений елемент творчості, оскільки в них так чи інакше виявляється особистість, обдарування, смаки, уподобання, рівень підготовки» [3, с. 57; 10, с. 42].

Творчі або підготовчі вправи, що використовуються вчителями на уроках рідної мови, $\epsilon$ допоміжними у процесі підготовки учнів до написання власне творчих робіт і допомагають дітям зрозуміти різноманітність наявних засобів вираження думок і почуттів, розвивають логічне мислення, тренують мозок. Тому у шкільній практиці широко використовуються такі види творчих вправ, як: творче списування, творчі диктанти, твори-мініатюри за опорними словами, твори за поданим початком чи кінцівкою, написання окремих видів ділових паперів. До творчих робіт належать і такі види переказів, у яких є елемент творчості: перекази зі зміною особи оповідача, сюжету, з доповненнями; різні види драматизації (від читання в особах до інсценізації); імпровізації учнів; ілюстрування творів за використання музичних творів. Вищою формою творчості учнів $є$ перші літературні спроби - вірші, проза, листування тощо.

Важливість мовних творчих робіт безсумнівна, оскільки їх використання не лише уможливлює закріплення знань, але й сприяє вдосконаленню здібностей учнів, прищепленню любові до художнього слова, вихованню високих моральних якостей. У письмових творах поєднуються логічні операції (аналіз, синтез, порівняння), словниковостилістична та лексико-граматична робота, реалізується спостережливість і життєвий досвід 
учнів. Якщо твір буде результатом свідомої роботи розуму і почуттів, продуктом власної творчості, то в ньому обов'язково відіб'ється особливість автора.

Цілком слушною видається пропозиція О. Полєвікової про те, що розробку методики роботи над творчими вправами слід здійснювати з урахуванням семи типів особистості учня: «Гравець словами» - учень, який має лінгвістичні здібності; «Допитливий аналітик» - учень, який має математичні здібності, логічно мислить; «Візуальний спостерігач»- учень, який потребує простору для навчання; «Любитель музики»- учень, який добре сприймає інформацію на слух; «Непосидючий»- фізично активний учень; «Співрозмовник»соціально активний учень; «Сам собі пан»- учень-індивідуаліст [7, с. 22].

Диференціація учнів за розгляданими критеріями дозволяє застосовувати такі методи активізації творчого пошуку, як: метод евристичної загадки, метод мозкової атаки, метод синектики Дж. Гордона, метод гірлянд запитань, метод ліквідації безвихідних ситуацій, метод фокальних об'єктів (МФО), тобто пошук нових ідей; прийоми пошуку евристичного мислення (Е. Де Боно), техніка сили розуму (Дж. Гр. Скотт), метод Метчета, евристичні прийоми розв'язання завдань (за Л. Дж. Фогелем, Д. Пойа, Ю. Кулюткіним), методи усвідомленологічного типу [7, с. 22].

Оскільки здібності дитини найкраще проявляються лише в тій діяльності, яка вимагає розвитку саме цих здібностей, то зрозуміло, що для розвитку творчих здібностей необхідна діяльність, яка містить у собі творчість. Тому не випадково, що на думку багатьох педагогів, ідеальним для розвитку творчості є навчання з використанням ігрових елементів, адже саме гра навчає таким обов'язковим для розвитку творчості здібностям, як моделювання, порівняння, узагальнення, конкретизація, навчання мистецтву доводити, прогнозувати тощо.

Науково доведено, що на основі ігрової діяльності в дитини формується низка психологічних новоутворень. Це передовсім уява та символічна функція свідомості, які дозволяють дитині здійснювати у своїх діях перенесення властивостей одних речей (фактів) на інші, а це, як відомо,- грунт для розвитку творчої діяльності. «Задовольняючи свою природну, невсипучу потребу в діяльності, у процесі гри учні «добувають» в уяві все, що недоступне їм у навколишній дійсності. У захопленні вони не помічають, що вчаться, розвивають фантазію» [12, с. 12]. Разом з тим, у дитини виникає осмислена орієнтація у власних переживаннях та їх узагальненні, на основі чого можуть бути сформовані навички їх культурного вираження.

3-поміж новітніх підходів до реалізації проблеми розвитку творчих здібностей школярів помітне місце посідає евристичний метод як частково-пошуковий метод організації творчої діяльності учнів на основі поелементарного засвоєння ними знань і способів діяльності.

Цей метод грунтується на висновках психології творчого або продуктивного мислення про те, що творчість - це норма дитячого розвитку; схильність до творчості, властивої будьякій дитині. Однак, беручи участь у творчій діяльності, дитина може діяти, керуючись певним зразком (пасивно-наслідувальна діяльність), може з багатьох пропонованих варіантів рішень самостійно обирати один (активно-наслідувальна діяльність), і нарешті, вона може придумати, створити якісно щось нове (творча діяльність). Кожен учень на певному етапі навчання спроможний до якогось $з$ окреслених типів діяльності більшою чи меншою мірою. Саме це й має враховувати вчитель.

Слід брати до уваги, що навчальний процес, спрямований на розвиток творчих здібностей, будується з урахуванням активності учнів. Тому вчителі планують педагогічні ситуації осмислено, з опорою на досягнення учнів, на те, що вони вміють, знають, 3 
урахуванням їх творчих можливостей.

На сьогодні перед учителями стоїть завдання не повідомити матеріал і перевірити знання учнів, а виявити досвід учнів щодо викладеної інформації. Тому й змінилася структура уроку: учні, як правило, співпрацюють у діалозі з учителем, висловлюють свої думки, діляться інформацією, обговорюють те, що пропонують однокласники, відбирають під керівництвом учителя той матеріал, що закріплений науковими знаннями.

Найголовніше завдання кожного вчителя в будь-якій ситуації- створити в класі атмосферу творчості, і більше того, вчитель має розуміти психологічну сутність цього процесу. Це насамперед не насильне навчання, а заохочення до пізнання, повага інтелектуальних сил дітей, що найкраще реалізуються в умовах інтерактивного навчання. Воно передбачає моделювання життєвих ситуацій, використання рольових ігор, дослідницьких проектів, творчих робіт, спільне розв'язання загальних, але важливих для кожного учасника навчального процесу завдань. Інтерактив виключає домінування одного доповідача над іншим і однієї думки над іншою. Саме цей тип навчання сприяє формуванню в учнів умінь критично мислити, розв'язувати складні проблеми на основі аналізу певних обставин і відповідної інформації, самостійно приймати виважені рішення, брати участь у дискусіях, спілкуватись і співпрацювати з іншими тощо [9, с. 24].

Отже, формування творчих здібностей молодших школярів у навчальний i позанавчальний час уможливлюється впровадженням у навчально-виховний процес молодших школярів інноваційних креативних технологій; проблемних, дослідницьких, евристичних, пошукових, ігрових методів навчання; застосуванням системи творчих вправ i завдань із урахуванням індивідуальних особливостей і рівня творчих можливостей дітей; створенням у класі атмосфери співтворчості й ситуації успіху кожному учневі, безперечно, через використання різних видів вербального і невербального заохочування.

\section{Література}

1. Выготский Л. С. Собрание сочинений: в 6 т. / Л. С. Выготский. - Москва : Просвещение, 1982. - Т. 1. - 423 с. 2. Вусик Г. Розвиток, формування та використання здібностей учнів у процесі шкільного навчання / Г. Вусик//УМЛШ. - 2001. - № 2. - С. 21-23. 3. Девдера М. В. Підвищення ефективності уроку з мови / М. В. Девдера // УМЛШ. - 1989. № 6. - С. 57-59. 4. Коновець С. Креативні освітні технології у практиці сучасної школи / С. Коновець // Початкова школа. - 2004. - № 10. - С. 20-23. 5. Кравцова І. А. Розвиток творчих здібностей молодших школярів засобами інтегрованих уроків: [метод. посіб.]/ I. А. Кравцова, А. С. Амброзяк. - Кривий Ріг : КДПУ, 2011. - 63 с. б. Максимова Н. Психологічні умови забезпечення розвитку творчого потенціалу учнів / Н. Максимова, Л. Порох // Початкова школа. - 2001. - № 5. - С. 18-20. 7. Моніторинг якості знань учнів початкової школи / Упорядник О. Б. Полєвікова. - Харків : Основа: «Тріада +», 2008. - 256 с.

8. Наумчук М. М. Словник-довідник основних термінів і понять з методики української мови: [навч.-метод. посіб.] / М. М. Наумчук, Л. П. Лушпинська. - Тернопіль: Астон, 2003. - 132 с. 9. Пометун О. Сучасний урок. Інтерактивні технології навчання / О. Пометун, Л. Пироженко. - К. : А.С.К., 2006. -192 с. 10. Порох Л. Розвиток творчої особистості школяра як психолого-педагогічна проблема сучасності / Л. Порох // УМЛШ. - 2001. - № 2. - С. 42-44. 11. Савченко О. Я. Розвиток пізнавальної самостійності молодших школярів / О. Я. Савченко. - Київ : Рад. школа, 1982. - 176 с. 12. Сологуб А. І. Креативна освіта. Навчальні дослідження в початковій школі / А. І. Сологуб, О. М. Швець. - Кривий Ріг : Видавничий дім, 2010. - 126 с. 13. Шпачук Л. Ігрове навчання. 2 клас: [навч.-метод. посіб.] / Л. Р. Шпачук, С. О. Швець. - Кривий Ріг : КДПУ, 2007. - 140 с. 